REVIEW

\title{
Protein Metabolism in Critical Illness: Methodologies and Their Problems Underlying in Kinetic Studies Using Isotope Tracers In Vivo
}

\author{
Yoichi Sakurai \\ Department of Surgery, Fujita Health University School of Medicine, Aichi, Japan
}

(Received for publication on November 18, 1998)

\begin{abstract}
The response to critical illness involves alterations in all aspects of metabolic control, favoring catabolism of body protein. In particular, as the result of the alteration of protein metabolism, body protein loss occurs, which has been reported to be inversely correlated with the survival of critically ill patients. Despite the availability of various therapeutic modalities aiming to prevent loss of body protein pool such as total parenteral nutrition, and enteral nutrition that has made to provide excessive calories as a form of energy substrate and protein itself, the loss of body protein could not be prevented. Loss of body protein store occurs as a consequence of the alteration of intermediate metabolism that works for the production of energy substrate. This alteration of substrate metabolism may link to the alteration of protein metabolism. However, no specific factors regulating protein metabolism have been identified. Thus, further investigations evaluating amino acid and protein metabolism are required to obtain a better understanding of the metabolic regulation in the body, which may lead to the development of novel and more effective therapeutic modalities for nutrition in the future. (Keio J Med 48 (2): 69-78, June 1999)
\end{abstract}

Key words: protein metabolism, nutritional support, stable isotope tracer, critical illness

\section{Introduction}

A rapid net catabolism of body protein, as well as a redistribution of the nitrogen pool and body composition within the body usually occurs in patients with major trauma, ${ }^{1.2}$ thermal injury, ${ }^{3.4}$ sepsis $^{5-7}$ and advanced cancer. ${ }^{8.9}$ Persistent protein loss from the body pauses an important clinical problem, because the survival rate in patients with these conditions is inversely proportional to the loss of lean body mass. ${ }^{10}$ Muscle protein breakdown is accelerated, whereas certain "acute-phase" proteins are produced at increased rates in the liver. Wound repair requires amino acids for protein synthesis, and increased immunological activity may also require accelerated protein synthesis. The magnitude of the net catabolism of muscle may be so pronounced that maintenance of lean body mass is an unreasonable goal in critically ill patients. Nonethe- less, provision of dietary protein and/or amino acid is essential for minimizing net protein catabolism and/or net protein loss. Although it seems likely that a higherthan-normal intake of protein may be useful, simple provision of enough calories and/or protein failed to efficiently improve the net protein loss. ${ }^{11}$ Even the mild stress of simple bed-rest increases the protein requirement to maintain nitrogen balance. ${ }^{12}$

This article reviews the alterations of amino acid and protein metabolism in critical illness and the response of nutritional support to amino acid and protein metabolism in vivo, and pathophysiological mechanisms by which amino acid and protein metabolism is altered in critical conditions are discussed. Underlying methodological issues involved in protein metabolism in vivo are also discussed. 
Characteristics of alteration in protein metabolism in critical illness

The in vivo alterations of protein kinetics have well been studied in patients with thermal injury, ${ }^{3,13-15}$ which could serve as a model of critical illness (Fig. 1). Accelerated muscle protein catabolism after thermal injury has been shown to persist for months. ${ }^{16}$ The principal defect is an accelerated rate of protein breakdown, and a failure of protein synthesis to increase that sufficiently occur to compensate. ${ }^{16}$ It has been believed that the breakdown of muscle protein is a major contributor to the overall catabolic responses in protein metabolism, ${ }^{17.18}$ because muscle tissue is the largest organ among the organs in the body in which body protein is stored. Therefore, the improvement of protein kinetics in muscle tissues has been the target in the nutritional support to prevent the loss of body protein. Despite the fact that a variety of nutritional support has been clinically used, none of the treatment has been successful to sufficiently restore body protein and for amino acid and protein kinetics to be normalized. Although the use of total parenteral nutrition (TPN) results in a decrease in the protein loss that accompanies critical surgical illness, only a minority of patients are rendered anabolic. ${ }^{19-21}$ Although the use of TPN results in a marked increase in whole body protein synthesis, ${ }^{20.21}$ and as a result of a major decrease in the rate of net protein loss, ${ }^{19}$ these patients remain in a state where net protein loss continues albeit at a slower rate than in the absence of TPN. One important reason of the inability for protein kinetics to be normalized is that the mechanism by which muscle protein catabolism

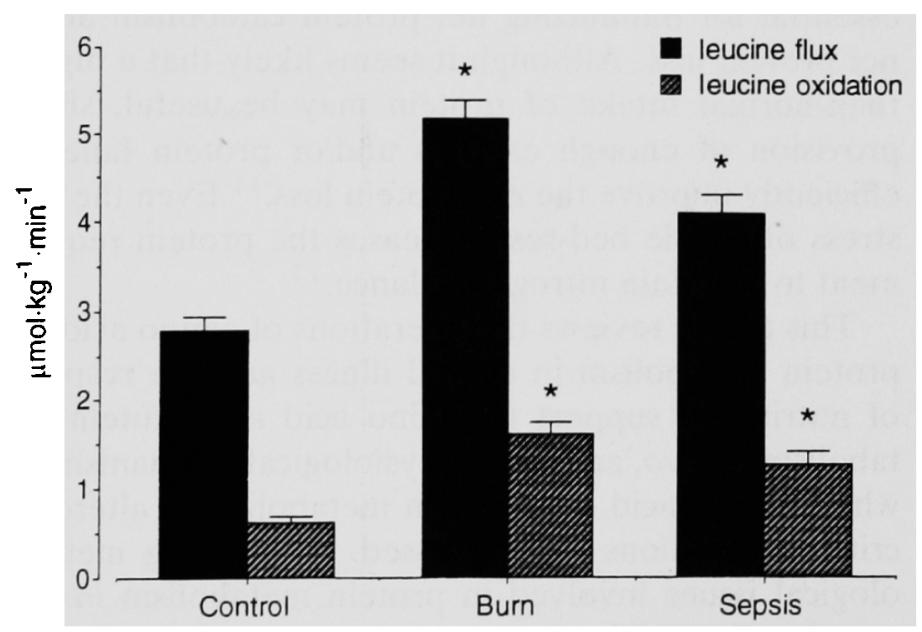

Fig. 1 Alterations of protein and amino acid metabolism in severelyburned patients. Parameters for protein and amino acid kinetics were obtained using a continuous infusion of leucine labeled with stable isotope. Leucine flux and leucine oxidation remarkably increased in burn and sepsis as compared with control (' $\mathrm{P}<0.05$ vs. Control). (From Ref. 14 with some modifications) occurs in patients with critical illness is not well understood. Furthermore, mediators of the increased rate of protein catabolism have not yet been identified. Although a number of hypotheses have been proposed in the past years, ${ }^{14,22-24}$ none have been verified to explain the alteration in protein catabolism in critical illness.

\section{Methodological issues involved in the measurement of protein metabolism}

Nitrogen balance studies: Nitrogen balance technique has been widely used as a gold standard for determining the balance between protein synthesis and breakdown at the whole body level. ${ }^{25}$ Although this technique requires no unprovable assumptions, the interpretation of $\mathrm{N}$-balance data is not as straightforward as would seem from its underlying principle. Hegsted ${ }^{26}$ collated nitrogen balance data and concluded that there is a systematic error inherent in the way $\mathrm{N}$-balance studies are performed. At protein intakes being above basal requirements, there is an apparent retention of approximately $20 \%$ of the extra nitrogen intake. In addition, this technique does not account for excretions of nitrogen from expired breath and sweat as a form of ammonia.

$\left.{ }^{15} \mathrm{~N}\right]$ glycine method: Constant infusion of ${ }^{15} \mathrm{~N}$ glycine is a method that was first used by Picou and Taylor-Roberts in $1969^{27}$ and has subsequently been used by a number of investigators. Among the assumptions that are needed to make for this method, the most practical problem is that when ${ }^{15} \mathrm{~N}$-glycine is infused without priming of amino acid and urea pools, as many as 30 to 40 hours may be necessary for obtaining a plateau of urinary urea. Likewise, since different tracer methods involve problems and need particular assumptions, these should be accounted for the appropriate interpretation of the results. Over the past 50 years, the study of amino acid and protein metabolism has been the predominant area of application of stable isotopic tracer methodology. This in part reflects the fact that ${ }^{15} \mathrm{~N}$ is a convenient stable isotope of nitrogen (the essential component of amino acids), and there is no other appropriate radioactive tracer of nitrogen.

\section{Urea kinetics as a model for net protein catabolism}

Net protein catabolism is also reflected by the measurement of urea production using $\left[{ }^{15} \mathrm{~N}_{2}\right]$ urea. ${ }^{28} \mathrm{Net}$ protein breakdown involves the oxidation of amino acids. In this process, the carbons of the amino acids are excreted in the breath as $\mathrm{CO}_{2}$, leaving nitrogen for disposal. The nitrogen produced in peripheral tissues is transported to the liver primarily in the forms of 
alanine and glutamine and urea is produced as a consequence of the reactions of urea cycle. ${ }^{28}$ The increase in urea production has been reported in weight losing cancer patients ${ }^{21}$ and in advanced gastrointestinal cancer patients. ${ }^{29}$ Whereas the rate of urea production is a reflection of net protein catabolism, not all the urea produced is excreted in the urine. Some urea diffuses from the blood into the gut, where bacteria contain the enzyme urease. This enzyme enables the bacteria to digest urea to $\mathrm{CO}_{2}$ and $\mathrm{NH}_{3}$. The $\mathrm{NH}_{3}$ can diffuse back into blood, where it is delivered to the liver by way of the portal circulation and can be incorporated into urea or amino acids. The rate of recycling of $\mathrm{N}$ into urea in humans varies from as little as $10 \%$ of production under normal conditions ${ }^{30}$ to more than $60 \%$ in pathological conditions. For example, in burn patients, $40 \%$ of urea produced is not excreted. ${ }^{11}$ Although the status of urea cycling has never been examined in patients with cancer, this mechanism could possibly be important for the understanding of protein balance in cancer patients.

\section{Constant essential amino acid tracer infusion}

Essential amino acids such as leucine and phenylalanine are the amino acids that unconditionally needed to maintain the integrity of the body, but are not synthesized in the body. However, certain concentration of these amino acids is maintained in plasma or intracellular space of the certain type of cells. These free essential amino acids found in either plasma or intracellular space are considered to be derived either from oral intake or from the breakdown of body protein. Thus, certain essential amino acid tracers labeled with stable isotope have been used to evaluate the in vivo rate of whole-body protein breakdown by measuring the rate of appearance of essential amino acid in plasma. For instance, leucine tracer is being used to calculate the rate of whole-body protein breakdown, in which a 2 hour primed-continuous infusion of stable isotopically labeled leucine tracer has been used. However, some of the branched-chain essential amino acid such as leucine is in part oxidized intracellularly producing alpha-keto acid. Therefore, the leucine appeared intracellularly as the result of protein breakdown is recycled in which leucine are reincorporated into protein before it appears in plasma. This leucine model enables to calculate the rate of whole-body protein synthesis by subtracting the rate of intracellular leucine oxidation from the rate of appearance of leucine, as well as the rate of protein breakdown. In contrast, because of the fact that phenylalanine that is also an essential amino acid is not oxidized in the cells, phenylalanine appeared in the cell and in plasma is considered to be generated solely as a result of protein breakdown in the circumstance where no phenylalanine is exogenously given.

\section{Flooding dose technique}

The rate of protein synthesis has been measured not only in the whole-body level but also in tissue level such as skeletal muscle. The method of choice for the measurement of the muscle protein synthesis rate most frequently used in humans has been a primed-constant infusion of an amino acid tracer. ${ }^{31}$ To calculate the rate of protein synthesis, this method requires measurement of the rate of incorporation of the labeled amino acid into protein and the precursor pool enrichment, i.e., the isotopic enrichment of the tracer at the site of protein synthesis. ${ }^{32}$ However, a major drawback of this method is the inability to measure the enrichment of the true precursor pool, i.e., the amino acyl-tRNA pool, because of the large tissue sample required and the tedious and elaborate procedure involved in its isolation and purification. To overcome this problem in human studies Garlick and co-workers ${ }^{33}$ adopted a flooding dose technique that requires considerably shorter period of the isotope infusion than the constant infusion method (1.5 versus $4-8$ hours) and permits an indirect estimate of the precursor pool enrichment by making measurements of the isotopic enrichment of the tracer amino acid in plasma. From the theoretical standpoint, the enrichment of the precursor pool can be accurately measured by analyzing plasma enrichment. Because in this flooding dose method, the labeled amino acid is given together with a large amount of unlabeled amino acid, it causes rapid equilibrium of the free extracellular amino acid pools, which enables to have the equal enrichment of the plasma as the enrichment of the precursor pool from which amino acids are used to charge tRNA for protein synthesis. However, the flooding dose method gives fractional muscle protein synthesis rates that are markedly greater than those obtained by the constant infusion method. ${ }^{34}$ One possible explanation for this discrepancy is a direct stimulatory effect of the large dose of amino acid or that of the hormonal response it elicits on protein synthesis rate. ${ }^{35}$

\section{$A-V$ difference techniques}

Measurement of tracer kinetics across a tissue bed has been used for many years in attempts to gain more information about the regional metabolism. Most commonly, metabolism of peripheral tissue is assessed by determining the balance of substrate and/or amino acids in and out from either the forearm or the leg. It is also possible to apply this model across the liver to determine the balance of substrate or amino acids in and out from the liver, although this model involves meth- 
odological difficulty in the placement of catheters in portal vein and hepatic vein in humans. Even when the isotopic tracers are not used, this arteriovenous (A-V) balance model enables to determine the net balance of substrate and amino acids across the tissue bed by measuring the concentrations of substrates or amino acids and the blood flow. This simple method without using isotopic tracers has classically been used for the last two decades to determine the metabolism of the peripheral tissue bed in critically ill patients. ${ }^{36-44}$ When isotopic tracers of amino acids are used, more information about the total rate of appearance (Rat) of a substrate across the tissue bed such as leucine or phenylalanine can be obtained (Fig. 2). The measurement of net balance using isotopic tracers requires the calculation of blood, substrate concentration in the artery and the vein, and isotopic enrichment in the artery and vein.

Possible mechanisms and/or hypotheses to explain the alteration in protein metabolism in critical illness

Inefficient substrate oxidation: Evidences indicate that resistance to the normal protein anabolic effect of insulin may be an important mechanism leading to net catabolism in severe injury or sepsis. ${ }^{+5-48} \mathrm{~A}$ general dysfunction of insulin during critical illness has been reported to be the failure of insulin to exert its normal hypoglycemic action. ${ }^{3,49}$ It has been proposed that the failure of insulin to normally stimulate glucose uptake and oxidation could lead to protein catabolism indirectly, as a consequence of a peripheral energy deficit. ${ }^{47,48}$ Another possible scenario is that because of the inability of insulin to restrain the stimulatory effect of glucagon on the rate of glucose production and gluconeogenesis, due to the increased plasma glucagon to insulin molar ratio, there is an increased rate of protein breakdown to supply amino acids as substrates to fuel the accelerated rate of gluconeogenesis. ${ }^{50,51}$ In other words, the recent work performed by Hesselgren et $a l .{ }^{45}$ indicated that in the skeletal muscle of septic rats there is an impairment of insulin to inhibit protein breakdown and to stimulate protein synthesis. To test the hypothesis that an increase in protein breakdown in critically ill patients is due to an impairment of peripheral glucose oxidation, Jahoor and Wolfe et al. ${ }^{14}$ performed a study in patients with burn and sepsis using a euglycemic hyperinsulinemic clamp technique combined with simultaneous administration of dichloroacetate (DCA), that stimulates pyruvate dehydrogenase activity, to further increase glucose oxidation. They found that the administration of DCA to the patients with burn and sepsis during hyperinsulinemia elicited a significant increase in the rate of glucose oxidation and the percentage of glucose uptake oxidized compared with the hyperinsulinemic clamp alone. However, the response of leucine and urea kinetics to the clamp with the simultaneous administration of DCA was not different from the response to the clamp alone. These results have suggested that the maximum effectiveness of insulin to suppress protein breakdown is not impaired and that a deficit in glucose oxidation or energy supply may not play a major role in mediating the protein catabolic response to severe burn injury and sepsis.

\section{Effects of catabolic hormones}

In stressed patients, several circulating factors regulating substrate, protein and energy metabolism have been identified. ${ }^{52.53}$ Glucagon, catecholamines and cortisol have been identified as the "stress hormones" that play important roles in critically ill conditions regulating substrate metabolism. ${ }^{53}$ These are supported by the animal study, in which blockade of the response of glucagon and insulin by the infusion of somatostatin and simultaneous adrenergic blockade abolished catabolic responses typically seen in septic condition. ${ }^{6}$ These hormones may partially be responsible for the catabolic response, because the administration of these hormones in normal human volunteers has been shown to reproduce many of the metabolic alterations observed during critical illness. ${ }^{54}$ Hyperglucagonemia was observed in

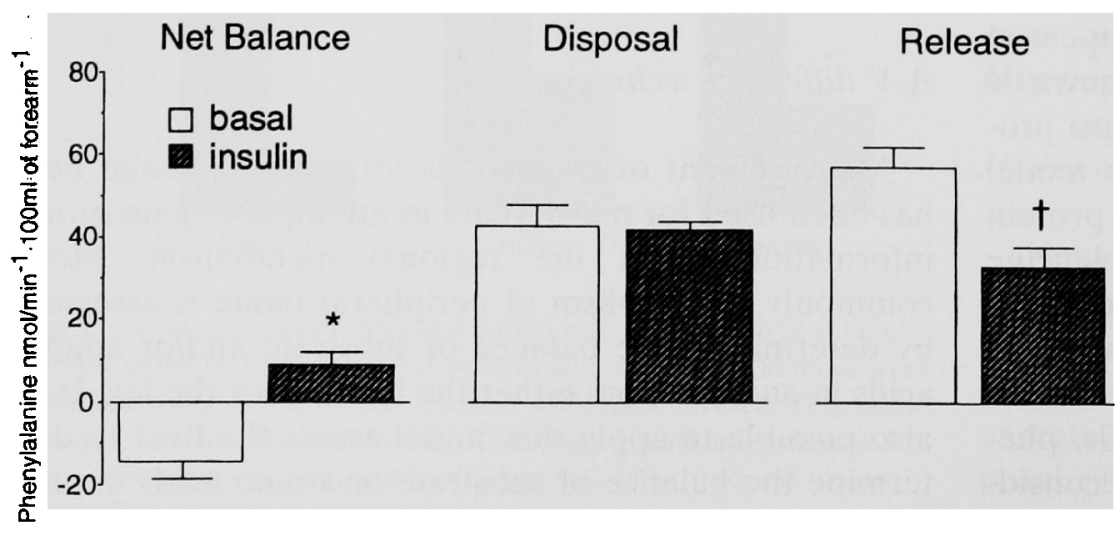

Fig. 2 Phenylalanine balance in and out from the forearm of the human volunteers. Infusion of stable isotope tracer of phenylalanine enables to calculate amino acid kinetics. Positive net balance is obtained after the local administration of insulin ( ${ }^{*} P<0.05$ vs. Basal). Positive net balance of phenylalanine is due to the significant decrease in release of phenylalanine from the forearm by the insulin infusion ( ${ }^{\dagger} P<0.01$ vs. Basal). (From Ref. 43) 
patients with certain types of cancer. ${ }^{55}$ Although stress hormones have clearly been shown to affect carbohydrate, lipid and protein metabolism, the factors that cause net protein catabolism have not yet been identified; the catabolic changes in protein metabolism observed in stressed patients cannot be precisely reproduced by stress hormone infusion. ${ }^{54}$

\section{Effects of inflammatory cytokines}

Recently, in addition to these classical regulatory and counter-regulatory hormones such as glucagon and catecholamines, inflammatory cytokines have been considered to be independent factors that also affect substrate and protein metabolism. ${ }^{56.57}$ The evidence that plasma concentration of tumor necrosis factor (TNF) is shown to be elevated in cancer patients also supports this theory, ${ }^{58}$ although this evidence has been still controversial. Therefore, it is reasonable to hypothesize that the changes in substrate metabolism in cancer patients are controlled by TNF. For example, TNF has been shown to cause cachexia, ${ }^{59}$ which is similar to the conditions frequently observed in cancer patients. Furthermore, TNF has also been shown to affect substrate and protein metabolism, in which TNF causes an increase in glucose production, glucose utilization, and essential amino acid oxidation, causing net protein catabolism. ${ }^{57}$ However, TNF inhibits lipolysis and free fatty acid flux. ${ }^{56.57}$ Thus, TNF alone cannot account for all the aspects of metabolic control, and other cytokines may contribute simultaneously to the overall metabolic responses in stressed patients. ${ }^{60}$ It has also been demonstrated that TNF causes changes in hormonal milieu, ${ }^{57.61}$ causing an increase in plasma glucagon concentration in sublethal doses and increase in glucagon and catecholamine concentration in lethal doses. ${ }^{61}$ Thus, alterations in substrate and protein metabolism seem to be controlled by complex mechanisms involving both classical regulatory and counter-regulatory hormones and cytokines.

Although the primary factors that control protein metabolism during critical illness have been identified, ${ }^{53}$ a possible mediator and/or humoral factor that causes the net protein catabolism during critical illness has not been identified. However, it has been recently demonstrated that cytokines are the candidates that regulate substrate and protein metabolism. ${ }^{57}$ Among the cytokines, TNF is a primary cytokine that plays a central role in the alteration in the overall systemic inflammatory response syndrome of critically ill patients. ${ }^{57,59,62}$ TNF also appears to elicit alterations in substrate and protein metabolism because infusion of TNF causes a state that is similar to the condition of the critically ill patients, that is so-called cachexia, ${ }^{59}$ (Fig. 3) although it is not clear whether the effects are direct or
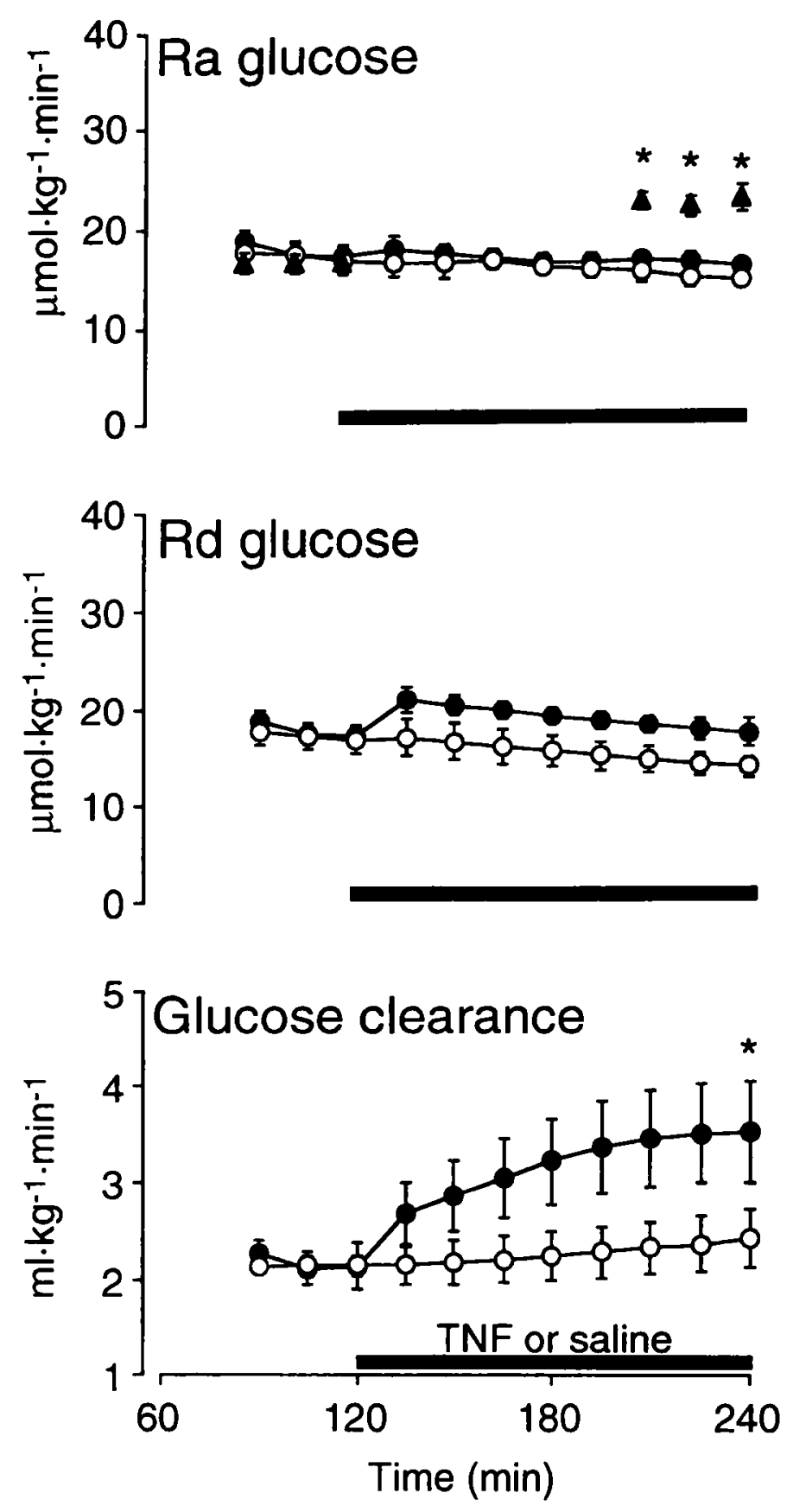

Fig. 3 Effects of TNF on amino acid and protein kinetics during hormonal clamp. TNF infusion causes increases in glucose uptake and leucine oxidation without being mediated by the changes in plasma glucagon and insulin concentration. $\mathrm{O}$, Placebo; $\Delta, \mathrm{TNF} ; \boldsymbol{\bullet}$. TNF with hormonal clamp. While a significant increase in glucose production during TNF infusion is abolished by the hormonal clamp, a significant increase in glucose clearance during TNF infusion is not affected (' $\mathrm{P}<0.05$ vs. Basal). (From Ref. 100 with some modifications)

secondary. Nonetheless, there is no doubt that TNF plays an important role in regulating substrate and protein metabolism. However, the fact that a number of cytokines have been shown to form network ${ }^{63}$ in vivo has hampered the determination of the precise roles of 
individual cytokine.

\section{Impaired transmembrane amino acid transport}

The failure of response of critically ill patients to nutritional support alone especially on protein metabolism has not been fully explained by a single theory for a long period of time. Although the prevention of body protein loss in the skeletal muscle has been the primary goal of the nutritional support, the thesis that inward amino acid transport is impaired in critical illness is the hypothesis that might explain the inability of nutritional support alone to improve the nutritional status of critically ill patients. This thesis has been supported by the results of recent studies in which inward amino acid transport via system A was inhibited in muscle from septic rats. ${ }^{64}$ Furthermore, incubation of fibroblasts with tumor necrosis factor significantly decreased inward system ASC-mediated glutamine transport activity. ${ }^{65} \mathrm{~A}$ reduction in the rate of inward transmembrane transport of amino acids could potentially leads to net protein catabolism. It has been demonstrated that free amino acids used for protein synthesis intracellularly are derived from two sources, protein breakdown and transmembrane amino acid transport from plasma to intracellular compartment of tissue cells such as skeletal muscle cells. ${ }^{66}$ When free amino acid influx from plasma compartment to intracellular pool is decreased, a higher-than-normal rate of protein breakdown is required to maintain normal concentrations of amino acids in the intracellular pool. This is possible, since the intracellular amino acid concentration apparently regulates muscle protein catabolism at least to some extent. ${ }^{67}$ If such an increase in protein breakdown occurred, corresponding increase in protein synthesis would not be likely, since there would not be an adequate increase in the availability of intracellular amino acids. This is based on the fact that intracellular amino acid concentration also appears to be a direct regulator of protein synthesis. ${ }^{17}$

We have recently demonstrated in normal $\operatorname{dogs}^{68}$ and humans ${ }^{66}$ that more than half of free intracellular amino acid pool used for protein synthesis is derived from intracellular protein breakdown and the rest is derived from plasma through the transmembrane amino acid transport. These evidences have been based on the three-compartment model we have recently developed in our laboratory. ${ }^{68}$ In physiological circumstances, the rates of amino acid transport in skeletal muscle were measured and it was found that the rates were different dependent on the amino acids. After exercise, the rates of amino acid transport were significantly increased and were associated with the increased rate of protein synthesis. ${ }^{69}$ This evidence suggests that intracellular free amino acids that are required for the

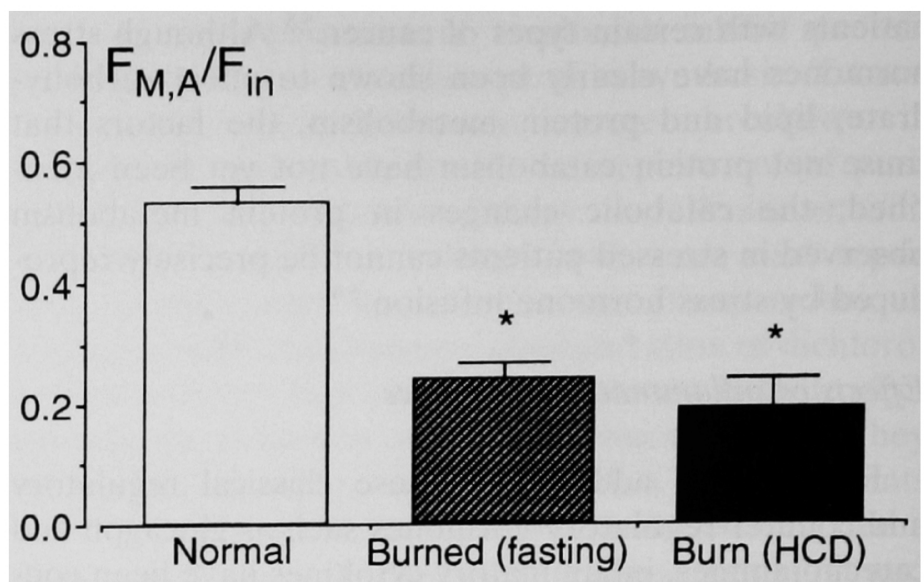

Fig. 4 Impaired amino acid transport of the skeletal muscle in severely-burned patients, which could be an important mechanism of negative protein balance of skeletal muscle that usually seen in severely-burned patients. $F_{\mathrm{M} . A} / F_{\text {in }}$ (a fraction of phenylalanine transported from plasma into skeletal muscle cells in the total phenylalanine that flows into the leg) is used as an indicator of the rate of amino acid transport ( $\mathrm{P}<0.05$ vs. Control). (From Ref. 71 with some modifications)

increased rate of protein synthesis in skeletal muscle are provided by the increased rate of amino acids in plasma that are transported by the transmembrane amino acid transport mechanism in cell membrane of the skeletal muscle. The rates of amino acid transport of skeletal muscle have been examined in burned patients. ${ }^{70-72}$ These studies clearly demonstrated an impairment of amino acid transport in skeletal muscle in burned patients, which may partially explain the negative protein balance and a loss of skeletal muscle mass in burned patients (Fig. 4). It has been shown that increased rates of protein breakdown and protein synthesis occur in the whole-body level ${ }^{14,73}$ and these alterations are attributable to the increased rates of protein breakdown and synthesis in skeletal muscle, ${ }^{70}$ since skeletal muscle is the largest organ for the body protein store. Due to an impairment of transmembrane inward amino acid transport in burned patients, free amino acid supply from plasma is decreased, despite larger quantity of free amino acids required for the increased rate of protein synthesis. The impairment of amino acid transport was not improved by the excessive calorie intake with enteral feeding ${ }^{71}$ or by the shortterm administration of insulin. Long-term pharmacological dose of insulin associated with high-carbohydrate enteral feeding improved the rate of amino acid transport. ${ }^{72}$ Although an impairment of amino acid transport in severely-burned patients is an important mechanism of negative protein balance of skeletal muscle, the question as to whether this mechanism could be extrapolated to other critically ill conditions remains to be solved. 
Changes in IGF-I and its binding proteins in critically ill conditions

Another possible mechanism responsible for an increased net protein catabolism is the marked depression in the circulating concentration of insulin-like growth factor I (IGF-I), an important anabolic hormone, after multiple mechanical injuries ${ }^{74}$ and thermal injuries. $^{74-79}$ Resistance to the anabolic effects of growth hormone has also been reported, especially in patients with the most severe injury. ${ }^{80}$ These evidences may provide a rationale for the exogenous administration of GH and/or IGF-I, which have been reported to increase nitrogen retention and to help preserve lean body mass after burn injury. ${ }^{72.81,82}$ Thus, absence of positive modulator is likely to be central to the derangement in protein metabolism observed in critically ill conditions. However, IGF-I exists in plasma with several binding proteins, which forms IGF-I and its binding protein (IGFBP) complex. Therefore, the complexity of protein bindings influences the availability and bioactivity of IGF-I. We have recently shown using A-V balance study that there is a net uptake of IGF-I and IGFBP in burned patients, ${ }^{83}$ which may partially explain a decrease in serum IGF-I concentration in burned patients. ${ }^{83}$ Despite the fact that further increase in IGF-I uptake is noted in response to continuous infusion of insulin, arterial IGF-I concentration increased, suggesting that insulin infusion stimulates IGF-I production. Serum concentrations of IGFBP-1, $2,-3$ and -4 are also altered in burned patients. ${ }^{83}$ IGF-I is associated with IGFBP-3 and acid labile subunit, forming ternary complex. which may be an important mechanism by which serum IGF-I is regulated. ${ }^{84}$ Thus, complex mechanism regulating IGF-I exists and it is not fully elucidated.

\section{Effect of exogenous anabolic hormone administration}

Since the report described by Wilmore et al. ${ }^{85} \mathrm{dem}$ onstrated that growth hormone increased nitrogen retention in patients with thermal injuries and receiving adequate calories and nitrogen, multiple studies have confirmed over the past 25 years the usefulness of anabolic hormone in reducing the negative nitrogen balance associated with severe protein loss. ${ }^{1+, 72.78,85-90}$ Insulin is the most important anabolic hormone liberated from pancreatic islet cell and has a tremendous effects on the regulation of substrate and protein metabolism. The physiological response of amino acid and protein metabolism to insulin has well been known in normal volunteers. ${ }^{36,43,91}$ Insulin also improves nitrogen balance in traumatized patients. ${ }^{46,92}$

Furthermore, insulin stimulates amino acid transport. ${ }^{93}$ In vitro and in vivo experiments have shown that insulin stimulates sodium-dependent system A amino acid transporter, in which alanine is the major substrate that has a large transmembrane concentration gradient. $^{9+-99}$ Recent study indicated that long-term high-dose insulin infusion associated with enteral feeding markedly stimulates transmembrane amino acid transport in skeletal muscle, resulting in the improvement of amino acid and protein balance in skeletal muscle in severely-burned patients. ${ }^{72}$ These results have provided an insight into the mechanism ivolved in the regulation of the balance of amino acid and protein kinetics in critically ill patients.

\section{Summary}

It has been long time since the alterations of protein kinetics in critical illness was reported, and various attempts in administering energy substrates and/or nutrients have been made to improve negative protein balance. However, none of the nutritional supports available so far have completely curtailed negative protein balance. Administration of anabolic hormone associated with energy substrates seems to be the most effective means available that efficiently improve protein kinetics. Although the mechanisms of alteration of protein kinetics have not been fully understood and none of the factors that directly regulate protein kinetics in critical illness have been identified, recent studies using tracer method have enable us to elucidate the mechanism involved in the alterations seen in critical illness. The impairment of amino acid transport in skeletal muscle may explain some aspects of the unresponsiveness of amino acid and protein kinetics to the administration of energy substrates and/or amino acids. Although it may not be conceivable to explain the alteration of protein kinetics by a single factor, several mechanisms and factors that are mainly responsible for the alterations of protein kinetics will be clarified in the future. Metabolic study using stable isotope tracers is an essential tool for in vivo quantitative evaluation of protein and amino acid kinetics.

Acknowledgments: The author thanks Drs. Takahiko Funabiki and Masahiro Ochiai (Professors of the Department of Surgery Fujita Health University, Toyoake, Aichi, JAPAN) for critical review, which were valuable contribution to this review.

\section{References}

1. Shaw JH, Wolfe RR: An integrated analysis of glucose, fat, and protein metabolism in severely traumatized patients. Studies in the basal state and the response to total parenteral nutrition. Ann Surg 1989; 209: 63-72

2. Shaw JH, Wolfe RR: Energy and protein metabolism in sepsis and trauma. Aust N Z J Surg 1987; 57: 41-47

3. Wolfe RR, Durkot MJ, Allsop JR, Burke JF: Glucose metabo- 
lism in severely burned patients. Metabolism 1979; 28: 10311039

4. Wolfe RR, O'Donnell TF Jr, Stone MD, Richmand DA, Burke JF: Investigation of factors determining the optimal glucose infusion rate in total parenteral nutrition. Metabolism 1980; 29 : $892-900$

5. Shaw JH, Wolfe RR: Response to glucose and lipid infusions in sepsis: a kinetic analysis. Metabolism 1985; 34: 442-449

6. Wolfe RR, Shaw JHF: Glucose and FFA kinetics in sepsis: role of glucagon and sympathetic nervous system activity. Am J Physiol 1985; 248: E236-E243

7. Shaw JH, Wolfe RR: Fatty acid and glycerol kinetics in septic patients and in patients with gastrointestinal cancer. The response to glucose infusion and parenteral feeding. Ann Surg 1987; 205: 368-376

8. Shaw JHF, Humberstone DA: Cancer: a metabolic parasite. $\mathrm{Br}$ J Surg 1988; 75: 1262

9. Sakurai Y, Klein S: Metabolic alteration in patients with cancernutritional implications. Surg Today 1998; 28: 247-257

10. Kinney JM: Metabolic responses to injuries. In: Winters RW, Green HL, eds, Nutritional Support of the Seriously Ill Patient, New York, Academic Press, 1983; 5-12

11. Wolfe RR, Goodenough RD, Burke JF, Wolfe MH: Response of protein and urea kinetics in burn patients to different levels of protein intake. Ann Surg 1983; 197: 163-171

12. Shangraw RE, Stuart CA, Prince MJ, Peters EJ, Wolfe RR: Insulin responsiveness of protein metabolism in vivo following bedrest in humans. Am J Physiol 1988; 255: E548-E558

13. Shangraw RE, Jahoor F, Miyoshi H, Neff WA, Stuart CA, Herndon DN, Wolfe RR: Differentiation between septic and postburn insulin resistance. Metabolism 1989; 38: 983-989

14. Jahoor F, Shangraw RE, Miyoshi $H$, Wallfish $H$, Herndon DN, Wolfe RR: Role of insulin and glucose oxidation in mediating the protein catabolism of burns and sepsis. Am J Physiol 1989; 257: E323-E331

15. Wolfe RR, Jahoor F, Herndon DN, Miyoshi H: Isotopic evaluation of the metabolism of pyruvate and related substrates in normal adult volunteers and severely burned children: effect of dichloroacetate and glucose infusion. Surgery 1991; 110: 54-67

16. Wolfe RR, Jahoor F, Hartl WH: Protein and amino acid metabolism after injury. Diabetes Metab Rev 1989; 5: 149-164

17. Bilmazes C, Kien CL, Rohrbaugh DK, Uauy R, Burke JF, Munro HN, Young VR: Quantitative contribution by skeletal muscle to elevated rates of whole-body protein breakdown in burned children as measured by $\mathrm{N}$ tau-methylhistidine output. Metabolism 1978; 27: 671-676

18. Long CL, Birkhahn RG, Geiger JW, Betts JE, Schiller WR, Blakemore WS: Urinary excretion of 3-methylhistidine: an assessment of muscle protein catabolism in adult normal subjects and during malnutrition, sepsis, and skeletal trauma. Metabolism 1981; 30: 765-776

19. Jeevanandam M, Horowitz GD, Lowry SF, Brennan MF: Cancer cachexia and protein metabolism. Lancet 1984; 1: 14231426

20. Burt ME, Stein TP, Brennan MF: A controlled, randomized trial evaluating the effects of enteral and parenteral nutrition on protein metabolism in cancer-bearing man. J Surg Res 1983; 34: 303-314

21. Shaw JH, Wolfe RR: Whole-body protein kinetics in patients with early and advanced gastrointestinal cancer: the response to glucose infusion and total parenteral nutrition. Surgery 1988; 103: $148-155$

22. Shaw JH, Wolfe RR: Metabolic intervention in surgical patients. An assessment of the effect of somatostatin, ranitidine, naloxone, diclophenac, dipyridamole, or salbutamol infusion on energy and protein kinetics in surgical patients using stable and radioisotopes. Ann Surg 1988; 207: 274-282

23. Wolfe RR: Counterregulatory hormones and human protein metabolism. In: Nair KS, ed, Protein Metabolism in Diabetes Mellitus, London, Smith Gordon \& Company, 1992; 207-213

24. Moldawer LL, Svaninger G, Gelin J, Lundholm KG: Interleukin 1 and tumor necrosis factor do not regulate protein balance in skeletal muscle. Am J Physiol 1987; 253: C766-C773

25. Scrimshaw NS, Hussein MA, Murray E, Rand WM, Young VR: Protein requirements of man: variations in obligatory urinary and fecal nitrogen losses in young men. J Nutr 1972; 102: 15951604

26. Hegsted DM: Assessment of nitrogen requirements. Am J Clin Nutr 1978; 31: 1669-1677

27. Picou D, Taylor-Roberts $T$ : The measurement of total protein synthesis and catabolism and nitrogen turnover in infants in different nutritional states and receiving different amounts of dietary protein. Clin Sci 1969; 36: 283-296

28. Wolfe RR, ed: Radioactive and Stable Isotope Tracers in Biomedicine: Principles and Practice of Kinetic Analysis, New York, Wiley-Liss, 1992

29. Shaw JH, Wolfe RR: Glucose and urea kinetics in patients with early and advanced gastrointestinal cancer: the response to glucose infusion, parenteral feeding, and surgical resection. Surgery 1987; 101: 181-191

30. Carraro F, Kimbrough TD, Wolfe RR: Urea kinetics in humans at two levels of exercise intensity. J Appl Physiol 1993; 75: 1180-1185

31. Rennie MJ: Muscle protein turnover and wasting due to injury and disease. Br Med Bull 1985; 41: 257-264

32. Waterlow JC, Garlick PJ, Millward DJ, eds: Protein Turnover in Mammalian Tissues and in the Whole Body, Amsterdam, North-Holland, 1978; 225-300

33. Garlick PJ, Wernerman J, McNurlan MA, Essen P, Lobley GE, Milne E, Calder GA, Vinnars E: Measurement of the rate of protein synthesis in muscle of postabsorptive young men by injection of a 'flooding dose' of $\left[1-{ }^{13} \mathrm{C}\right]$ leucine. Clin Sci 1989; 77 : 329-336

34. Jahoor F, Zhang XJ, Baba H, Sakurai Y, Wolfe RR: Comparison of constant infusion and flooding dose techniques to measure muscle protein synthesis rate in dogs. J Nutr 1992; 122: 878-887

35. Garlick PJ, Grant I: Amino acid infusion increases the sensitivity of muscle protein synthesis in vivo to insulin. Effects of branched-chain amino acids. Biochem J 1988; 254: 579-584

36. Tessari P, Trevisan R, Inchiostro S, Biolo G, Nosadini R, De Kreutzenberg SV, Duner E, Tiengo A, Crepaldi G: Doseresponse curves of effects of insulin on leucine kinetics in humans. Am J Physiol 1986; 251: E334-E342

37. Tessari P, Biolo G, Inchiostro S, Saggin L, Piccoli A, Tiengo A: Relationship between plasma leucine concentration and clearance in normal and type 1 diabetic subjects. Acta Diabetol 1992; 29: 6-10

38. Hummel RP 3rd, Warner BW, James JH, Hasselgren PO, Fischer JE: Effects of indomethacin and leupeptin on muscle cathepsin B activity and protein degradation during sepsis. J Surg Res 1988; 45: 140-144

39. Tessari P, Inchiostro S, Biolo G, Vincenti E, Sabadin L: Effects of acute systemic hyperinsulinemia on forearm muscle proteolysis in healthy man. J Clin Invest 1991; 88: 27-33

40. Tessari P, Nissen SL, Miles JM, Haymond MW: Inverse relationship of leucine flux and oxidation to free fatty acid availability in vivo. J Clin Invest 1986; 77: 575-581

41. Tessari P, Inchiostro S, Biolo G, Trevisan R, Fantin G, Marescotti MC, Iori E, Tiengo A, Crepaldi G: Differential effects of hyperinsulinemia and hyperaminoacidemia on leucine-carbon metabolism in vivo. Evidence for distinct mechanisms in regu- 
lation of net amino acid deposition. J Clin Invest 1987; 79 : 1062-1069

42. Louard RJ, Fryburg DA, Gelfand RA, Barrett EJ: Insulin sensitivity of protein and glucose metabolism in human forearm skeletal muscle. J Clin Invest 1992; 90: 2348-2354

43. Gelfand RA, Barrett EJ: Effect of physiologic hyperinsulinemia on skeletal muscle protein synthesis and breakdown in man. $J$ Clin Invest 1987; 80: 1-6

4. Fryburg DA, Gelfand RA, Barrett EJ: Growth hormone acutely stimulates forearm muscle protein synthesis in normal humans. Am J Physiol 1991; 260: E499-E504

45. Hasselgren PO, Warner BW. James JH. Takehara H, Fischer JE: Effect of insulin on amino acid uptake and protein turnover in skeletal muscle from septic rats. Evidence for insulin resistance of protein breakdown. Arch Surg 1987; 122: 228-233

46. Inculet RI, Finley RJ, Duff JH, Pace R. Rose C, Groves AC. Woolf LI: Insulin decreases muscle protein loss after operative trauma in man. Surgery $1986 ; 99: 752-758$

47. Ryan NT, Blackburn GL, Clowes GHA Jr: Differential tissues sensitivity to elevated endogenous insulin levels during experimental peritonitis in rats. Metabolism 1974; 23: 1081-1089

48. Ryan NT, George BC, Egdahl DH, Egdahl RH: Chronic tissue insulin resistance following hemorrhagic shock. Ann Surg 1974: 180: $402-407$

49. Sakurai Y, Ochiai M, Funabiki T: Significance of in vivo glucose kinetics using stable isotope tracers: alteration of glucose kinetics in humans during critical illness. Surg Today (in press)

50. Clowes GHA Jr, O'Donnell TF, Blackburn GL, Maki TN: Energy metabolism and proteolysis in traumatized and septic man. Surg Clin North Am 1976; 56: 1169-1184

51. Gump FE, Kinney JM: Energy balance and weight loss in burned patients. Arch Surg 1971; 103: 442-448

52. Ryan NT: Metabolic adaptations for energy production during trauma and sepsis. Surg Clin North Am 1976; 56: 1073-1090

53. Wilmore DW: Hormonal responses and their effect on metabolism. Surg Clin North Am 1976; 56: 999-1018

54. Bessey PQ, Watters JM, Aoki TT. Wilmore DW: Combined hormonal infusion simulates the metabolic response to injury. Ann Surg 1984: 200: 264-281

55. Burt ME, Aoki TT, Gorschboth CM, Brennan MF: Peripheral tissue metabolism in cancer-bearing man. Ann Surg 1983; 198 : 685-691

56. Sakurai Y, Zhang XU, Wolfe RR: Short-term effects of tumor necrosis factor on energy and substrate metabolism in dogs. $J$ Clin Invest 1993; 91: 2437-2445

57. Sakurai Y, Zhang X. Wolfe RR: Effect of tumor necrosis factor on substrate and amino acid kinetics in conscious dogs. Am J Physiol 1994; 266: E936-E945

58. Stovroff MC, Fraker DL, Norton JA: Cachectin activity in the serum of cachectic, tumor-bearing rats. Arch Surg 1989; 124: 94-99

59. Tracey KJ, Wei H, Manogue KR. Fong Y. Hesse DG, Nguyen HT, Kuo GC, Beutler B, Cotran RS, Cerami A, Lowry SF: Cachectin/tumor necrosis factor induces cachexia, anemia, and inflammation. J Exp Med 1988; 167: 1211-1227

60. Hesse DG. Tracey KJ, Fong Y, Manogue KR, Palladino MA, Jr, Cerami A, Shires GT. Lowry SF: Cytokine appearance in human endotoxemia and primate bacteremia. Surg Gynecol Obstet 1988; 166: 147-153

61. Tracey KJ, Lowry SF, Fahey TJ 3rd, Albert JD, Fong Y, Hesse D, Beutler B, Manogue KR, Calvano S, Wei H. Cerami A, Shires T: Cachectin/tumor necrosis factor induces lethal shock and stress hormone responses in the dog. Surg Gynecol Obstet 1987; 164: 415-422

62. Van der Poll T, Romijn JA, Endert E, Borm JJ, Büller HR, Sauerwein HP: Tumor necrosis factor mimics the metabolic re- sponse to acute infection in healthy humans. Am J Physiol 1991; 261: E457-E465

63. Bellomo R: The cytokine network in the critically ill. Anaesth Intensive Care 1992; 20: 288-302

64. James JH, Hasselgren PO, Hummel RP 3rd, Warner BW, Fischer JE: Effect of sepsis on amino acid transport system $A$ and its response to insulin in incubated rat skeletal muscle. Metabolism 1990; 39: 335-340

65. Dudrick PS, Bland KI, Souba WW: Effects of tumor necrosis factor on system ASC-mediated glutamine transport by human fibroblasts. J Surg Res 1992; 52: 347-352

66. Biolo G, Fleming RYD, Maggi SP, Wolfe RR: Transmembrane transport and intracellular kinetics of amino acids in human skeletal muscle. Am J Physiol 1995; 268: E75-E84

67. Flakoll PJ, Kulaylat M, Frexes-Steed M, Hourani H, Brown LL, Hill JO, Abumrad NN: Amino acids augment insulin's suppression of whole body proteolysis. Am J Physiol 1989; 257: E839-E847

68. Biolo G, Chinkes D, Zhang XJ. Wolfe RR: Harry M. Vars Research Award. A new model to determine in vivo the relationship between amino acid transmembrane transport and protein kinetics in muscle. JPEN J Parenter Enteral Nutr 1992; 16: 305315

69. Biolo G, Maggi SP, Williams BD, Tipton KD, Wolfe RR: Increased rates of muscle protein turnover and amino acid transport after resistance exercise in humans. Am $J$ Physiol 1995; 268: E514-E520

70. Biolo G, Maggi SP, Fleming RYD, Herndon DN, Wolfe RR: Relationship between transmembrane amino acid transport and protein kinetics in muscle tissue of severely burned patients. Clin Nutr 1993; 12(Suppl 2): 4

71. Sakurai Y, Wolfe RR, Herndon DN, Funabiki T: Effects of long-term high-carbohydrate enteral feeding on transmembrane amino acid transport in severely burned patients. Surg Forum 1996; 47: 29-31

72. Sakurai Y, Aarsland A, Herndon DN, Chinkes DL, Pierre E. Nguyen TT, Patterson BW. Wolfe RR: Stimulation of muscle protein synthesis by long-term insulin infusion in severely burned patients. Ann Surg 1995; 222: 283-297

73. Jahoor F. Desai M. Herndon DN, Wolfe RR: Dynamics of the protein metabolic response to burn injury. Metabolism 1988; 37 : 330-337

74. Coates CL, Burwell RG, Carlin SA, Milligan GF, Littlejohn S, London PS. Selby C. Swannell AJ: The somatomedin activity in plasma from patients with multiple mechanical injuries: with observations on plasma cortisol. Injury 1981: 13: 100-107

75. Ghahary A, Fu S, Shen YJ, Shankowsky HA, Tredget EE: Differential effects of thermal injury on circulating insulin-like growth factor binding proteins in burn patients. Mol Cell Biochem 1994; 135: 171-180

76. Strock LL. Singh H, Abdullah A, Miller JA, Herndon DN: The effect of insulin-like growth factor I on postburn hypermetabolism. Surgery 1990; 108: 161-164

77. Jeffries MK, Vance ML: Growth hormone and cortisol secretion in patients with burn injury. J Burn Care Rehabil 1992; 13: 391-395

78. Cioffi WG, Gore DC, Rue LW 3rd, Carrougher G, Guler HP, McManus WF, Pruitt BA Jr: Insulin-like growth factor-1 lowers protein oxidation in patients with thermal injury. Ann Surg 1994: 220: 310-319

79. Abribat T, Brazeau P, Davignon I, Garrel DR: Insulin-like growth factor-I blood levels in severely burned patients: effects of time post injury, age of patient and severity of burn. Clin Endocrinol (Oxf) 1993; 39: 583-589

80. Dahn MS, Lange MP, Jacobs LA: Insulinlike growth factor 1 production is inhibited in human sepsis. Arch Surg 1988; 123: 
$1409-1414$

81. Herndon DN, Barrow RE, Kunkel KR, Broemeling L, Rutan RL: Effects of recombinant human growth hormone on donorsite healing in severely burned children. Ann Surg 1990; 212: 424-431

82. Gilpin DA. Barrow RE. Rutan RL, Broemeling L, Herndon DN: Recombinant human growth hormone accelerates wound healing in children with large cutaneous burns. Ann Surg 1994; 220: $19-24$

83. Lang CH. Fan J, Frost RA, Gelato MC, Sakurai Y, Herndon DN, Wolfe RR: Regulation of the insulin-like growth factor system by insulin in burn patients. J Clin Endocrinol Metab 1996; 81: 2474-2480

84. Bereket A, Wilson TA, Blethen SL, Sakurai Y, Herndon DN, Wolfe RR, Lang CH: Regulation of the acid-labile subunit of the insulin-like growth factor ternary complex in patients with insulin-dependent diabetes mellitus and severe burns. Clin Endocrinol (Oxf) 1996; 44: 525-532

85. Wilmore DW, Moylan JA Jr, Bristow BF, Mason AD Jr, Pruitt BA $\mathrm{J} r$ : Anabolic effects of human growth hormone and high caloric feedings following thermal injury. Surg Gynecol Obstet 1974; 138: 875-884

86. Manson JM. Smith RJ, Wilmore DW: Growth hormone stimulates protein synthesis during hypocaloric parenteral nutrition. Role of hormonal-substrate environment. Ann Surg 1988; 208: 136-142

87. Brooks DC. Bessey PQ, Black PR, Aoki TT, Wilmore DW: Insulin stimulates branched chain amino acid uptake and diminishes nitrogen flux from skeletal muscle of injured patients. J Surg Res 1986; 40: 395-405

88. Ziegler TR, Young LS, Ferrari-Baliviera E, Demling RH, Wilmore DW: Use of human growth hormone combined with nutritional support in a critical care unit. JPEN $J$ Parenter Enteral Nutr 1990; 14: 574-581

89. Herndon DN, Hayward PG, Rutan RL, Barrow RE: Growth hormones and factors in surgical patients. Adv Surg 1992; 25: 65-97

90. Gore DC, Honeycutt D, Jahoor F, Wolfe RR, Herndon DN:
Effect of exogenous growth hormone on whole-body and isolated-limb protein kinetics in burned patients. Arch Surg 1991; 126: $38-43$

91. Fukagawa NK, Minaker KL, Rowe JW, Goodman MN, Matthews DE, Bier DM, Young VR: Insulin-mediated reduction of whole body protein breakdown. Dose-response effects on leucine metabolism in postabsorptive men. J Clin Invest 1985; 76: 2306-2311

92. Powell-Tuck J, Fern EB, Garlick PJ, Waterlow JC: The effect of surgical trauma and insulin on whole-body protein turnover in parenterally-fed undernourished patients. Hum Nutr Clin Nutr 1984; 38: 11-22

93. Biolo G, Declan Fleming RY, Wolfe RR: Physiologic hyperinsulinemia stimulates protein synthesis and enhances transport of selected amino acids in human skeletal muscle. J Clin Invest 1995; 95: 811-819

94. Guidotti GG, Borghetti AF, Gazzola GC: The regulation of amino acid transport in animal cells. Biochim Biophys Acta 1978; 515: 329-366

95. Shotwell MA, Kilberg MS, Oxender DL: The regulation of neutral amino acid transport in mammalian cells. Biochim Biophys Acta 1983; 737: 267-284

96. Christensen HN: Role of amino acid transport and countertransport in nutrition and metabolism. Physiol Rev 1990; 70: 43-77

97. Hundal HS, Rennie MJ, Watt PW: Characteristics of acidic, basic and neutral amino acid transport in the perfused rat hindlimb. J Physiol (Lond) 1989; 408: 93-114

98. Guidotti GG, Gazzola GC: Amino acid transporters: systematic approach and principles of controls. In: Kilberg MS, Haüssinger D, eds, Mammalian Amino Acid Transport, New York, Plenum Publishing Corp, 1992; 3-29

99. Bonadonna RC, Saccomani MP, Cobelli C, DeFronzo RA: Effect of insulin on system $A$ amino acid transport in human skeletal muscle. J Clin Invest 1993; 91: 514-521

100. Sakurai Y, Zhang XJ, Wolfe RR: TNF directly stimulates glucose uptake and leucine oxidation and inhibits FFA flux in conscious dogs. Am J Physiol 1996; 270: E864-E872 